\title{
Hasta ve Hasta Yakınlarının İnvaziv Girişimler Sırasındaki Tepkilerinin Hemşireler Üzerindeki Etkisinin İncelenmesi
}

\section{Investigation of the Effect of Reaction of Patients and Patients' Relatives During Invasive Interventions on Nurses}

\author{
Merve $\operatorname{Karadaş}^{1}$ (iD) Leman Şenturan ${ }^{2-(i D)}$ \\ ${ }^{1}$ Kanuni Sultan Süleyman Eğitim ve Araștırma Hastanesi, İstanbul, TÜRKIYE \\ ${ }^{2}$ Biruni Üniversitesi, Sağlık Bilimleri Fakültesi Hemşirelik Bölümü, İstanbul, TÜRKIYE \\ Geliş tarihi/ Date of receipt: 26/03/2021 Kabul tarihi/ Date of acceptance: 21/06/2021 \\ (c) Ordu University Faculty of Health Sciences, Department of Nursing, Turkey, Published online: 08/09/2021
}

ÖZ

Amaç: Araştırma, invaziv girişimler sırasında hasta ve hasta yakınlarının tepkilerinin hemşireler üzerindeki etkisini incelemek amaciyla yapild 1 .

Yöntem: Tanımlayıcı tipteki araştırmanın evrenini 600 hemşire; örneklem ise, çalışıkları ünitelerde refakaţ̧i bulunan ve hastalarına invaziv girişim yapılan 240 hemşire oluşturdu. Veriler, 33 soruluk anket formu ile toplandı. Çalışma için kurum izni ve etik kurul onayı alındı. Çalı̧̧ma verileri değerlendirilirken, dağılım ölçütleri ile Shapiro Wilks testi, Ki-Kare testi, Continuity (Yates) Düzeltmesi ve Fisher Kesin Ki-Kare kullanıldı. Anlamlılık $\mathrm{p}<0.05$ düzeyinde kabul edildi.

Bulgular: Araştırmaya katılan hemşirelerin \%76.3'ü 18-35 yaş arasında; \%52.1'i lisans mezunu; \%70.4'ü kadın ve \%77.9'u üniversite hastanesinde çalıșmaktayd. İnvaziv girișimler sırasında hemşirelerin \%27.5'inin el tutma, \%15'inin üstüne yürüme ve \%49.6'sının yüksek sesle konuşma gibi müdahalelerle karşı karşıya kaldığı görüldü. Özel hastanede çalışan hemşirelerin hasta ve hasta yakınlarının davranışları nedeniyle stres yaşama oranı üniversite hastanesinde çalıșan hemşirelerden istatistiksel olarak anlamlı düzeyde yüksek olduğu belirlendi $(\chi 2=5.911)(\mathrm{p}=0.015)$. Hemşirelerin invaziv girișimler sırasında $\% 62.9$ 'unun stres yaşadığı; $\% 51.3$ ' ünün uygulamalar sırasında hata yapma korkusu yaşadığı, \%25.4'ünün müdahale edildiğinde hastanın odasına tekrar girmekten çekindiği şeklinde etkilendikleri belirlendi.

Sonuç: Araş̧ırmada hasta ve yakınlarının invaziv girişimler sırasında hemşirelerin elini tutma, eline vurma, üstüne yürüme, kötü söz söyleme, yüksek sesle konusma, ve tehdit edilme gibi müdahalelerde bulundukları; bu müdahale ve davranışların hemşireleri olumsuz etkilediği; hemşirelerin bu duruma farklı tepkiler gösterdiği sonucuna varıldı.

Anahtar Kelimeler: hasta, hasta yakını, invaziv girişim, hemşire

ABSTRACT

Objective: The research was to examine the effect of interventions of patients and patient relatives on nurses during invasive procedures.

Methods: The research was carried out descriptively. The sample consisted of 240 nurses who worked in units where patients were accompanied by relatives and underwent invasive interventions. The data were collected through a survey. While evaluating the study data, Shapiro Wilks test, Chi-Square test, Continuity (Yates) Correction and Fisher Exact Chi-Square were used with distribution criteria.

Results: During invasive procedures, $27.5 \%$ of the nurses faced interventions such as grabbing their hands, $15 \%$ were threatened by walking over them, and $49.6 \%$ were shouted loudly. $62.9 \%$ of the nurses experienced stress during invasive procedures; It was seen that $51.3 \%$ were afraid of making mistakes during the applications and $25.4 \%$ were afraid to re-enter the patient's room when intervened. During invasive procedures, it was determined that $62.9 \%$ of the nurses experienced stress, $51.3 \%$ were afraid of making mistakes during the procedures and $25.4 \%$ were afraid to re-enter the patient's room when intervened.

Conclusion: In the study, it was concluded that the patients and their relatives intervened during the invasive procedures such as grabbing the hand of the nurses, hitting their hand, walking up to them, saying bad words, speaking loudly and threatening. It was also concluded that these interventions and behaviors affect the nurses negatively and the nurses show different reactions to this situation. Key words: patient, patient relative, invasive procedures, nurse

\footnotetext{
ORCID IDs of the authors: MK: 0000-0002-2069-3081; LŞ: 0000-0001-7951-6971

Sorumlu yazar/Corresponding author: Prof. Dr. Leman ŞENTURAN

Biruni Üniversitesi, Sağlık Bilimleri Fakültesi Hemşirelik Bölümü, İstanbul, TÜRKIYYE

e-posta/e-mail: 1senturan@biruni.edu.tr

Atıf/Citation: Karadas M, Senturan L. (2021). Hasta ve Hasta Yakınlarının İnvaziv Girişimler Sırasındaki Tepkilerinin Hemșireler Üzerindeki Etkisinin İncelenmesi. Ordu Üniversitesi Hemşirelik Çalışmaları Dergisi, 4(2), 172-180. DOI: 10.38108/ouhcd.903744
} 


\section{Giriş}

Hemşirelik, insana bütüncül olarak yaklaşan ve bu doğrultuda bakım veren ve gerekli hemşirelik girişimlerini uygulayan sağlık disiplinidir (Potter ve ark., 2009). Hemşirenin bakım ve tedavi ile ilgili uygulamalarının birçoğu invaziv girişimlerden oluşmaktadır (Holland ve ark., 2008). Tip ve hemşirelik literatüründe invaziv kelimesi "vücudun delinmesi, kesi veya delip geçilmesi ile vücut bütünlüğünün bozulması" olarak ifade edilmektedir (Sabuncu ve Akça Ay, 2010; Zungola, 2003). Hemşirelerin yaptığı tedavi uygulamalarının ve bazı bakım girişimlerin birçoğu, hastaya acı, ağnı endişe veren invaziv uygulamaları kapsar. Her bir invaziv girişim hasta için stres ya da endişeye neden olan stresör olarak kabul edilebilir. Dolayısıyla hastalar bu uygulamalara karşı isteyerek ya da istemsiz olarak farklı tepkiler verebilmektedirler.

Sağlıklı/hasta birey ile kurulan kişilerarası ilişki, hemşirelerin elinde bulunan önemli bir bakım ve tedavi aracıdır ve hastalığın gidişatı ve sonucunu etkileyen önemli etmenlerden biridir (Toru, 2020). Kişilerarası ilişkiler aracılığı ile hemşire bireyi bütüncül olarak, tüm boyutları, gereksinimleri, ailesi, diğer yakın ve geniş çevresi ile ele alır; bireyselliğine, eşsizliğine ve değerliliğine önem verir (Brilowski ve Wendler, 2005). Bu bağlamda kurulan ilişki kendiliğinden ve rastgele değil, terapötik bir iliş̧idir (Yalçın ve Aştı, 2011). Hemşire ve birey arasındaki ilişki hemen gerçekleşmez. Hemşire iletişimi başlatır, yönetir ve etkileşim için sorumluluk alır (Potter ve ark., 2009). Hemşire kuramcıların birçoğu hemşireliği "kişilerarası bir etkileşim süreci" olarak tanımlamaktadır (Cosette ve ark., 2005; Potter ve ark., 2009; Bayat, 2010; Yalçın ve Aşt1, 2011; Akduran ve Özkan, 2014; Ay ve ark., 2017). Etkileșim; en az iki kişinin, birbirini etkilediği ve birbirinden etkilendiği, sözlü ve sözsüz yollarla iletişimde bulundukları bir durumdur. Bireyhemşire etkileşimi, bireysel beklenti, amaç, gereksinim ve değerleri olan iki yabancının işlevsel yakınlığı olarak ele alınabilir (Yalçın ve Aştı, 2011). Hemşirelik inanç ve değer sistemini oluşturan, düşünce ve uygulamalarına yön veren hümanistik yaklaşım, yapıcı, etkin bir etkileşim üzerine kurulmuştur (Toru, 2020; Yalçın Atar ve Așt1, 2012). Tüm hemşirelik işlevlerinde birey-hemşire arasında bir etkileşim gerçekleşmektedir. Hemşire ve hasta birey arasındaki etkileşim, karşlıklı ilişki içerisinde olma ve güven ile şekillenir. Bu ilişkinin sağlanması ve etkileşimin gerçekleşmesini etkileyen sosyo-kültürel, biyofizyolojik, psikolojik, politiko- ekonomik etmenler tarafindan şekillenen tutumlar bulunmaktadır (Haworth ve Dluhy, 2001; Yalçın ve Așt1, 2011). Bu etkileşim iki yönlüdür. Bununla birlikte bu etkileşimden hemşireler de etkilenebilmektedirler. Hemşire, tutum, davranış ve hemşirelik girişimleri ile hasta bireyi etkiler ve ondan etkilenir (Tutuk ve ark., 2002; Özcan, 2006).

Bütün hemşirelik girişimlerinde hemşire-hasta arasında bir etkileşim söz konusudur. İnvaziv girişimler, hemşire- hasta ve hasta yakınları arasındaki ilişkiyi olumlu ve olumsuz etkileyebilir. Özellikle ağrılı uygulamaların söz konusu olduğu invaziv hemşirelik uygulamaları sırasında, hastanın etkilenmesi kadar, hemşireler de etkilenebilmektedir. Girişimin doğası nedeniyle başarısızlıkla sonuçlanabilen ya da sık tekrarlayan ağrilı ve rahatsızlı yaratan uygulamalarda etkileşimi yürütmek zor olabilmektedir. Böyle bir durumda hastanın ya da yakınlarının tepkileri hemşireler için bir stresör olabildiği için hemşireler de etkilenebilmektedir. Hemșirelerin tedavi ve bakım uygulamaları sirasında, hasta yakınları tarafindan kendilerine müdahale edilmesinin onları nasıl etkilediği ile ilgili yapılacak incelemeler çözüm olanakları için literatüre katkı sağlayacaktır.

Hastalar ve hasta yakınları, hemşirelerin gerçekleştirdikleri invaziv girişimlere farklı biçimlerde müdahale etmekte/tepki gösterebilmektedirler. Yapılan müdahale ve tepkilerin hemşirelik işlemlerini etkileyebileceği düşüncesinden yola çıkılarak yürütülen bu araştırmanın amacı invaziv girişimler sırasında hasta ve hasta yakınlarının hemşirelere gösterdikleri tepkilerinin hemşireler üzerindeki etkisini incelemektir.

\section{Yöntem}

Tanımlayıcı tipte olan araștırma, Ocak-Haziran 2016 tarihleri arasında biri özel diğer üniversite hastanesi olmak üzere iki kurumda yürütülmüştür. Araştırmanın evrenini bu hastanelerde çalışan 600 hemşire oluşturmaktadır. Araştırmanın örneklemi güç analizi yapılarak 0.05 yanılg1 düzeyi, 0.95 güven aralığında 175 olarak hesaplanmıştır. Ancak örneklem seçimi yapılmamış, hastanın yanında refakatçisinin bulunduğu ve invaziv hemşirelik girişimlerin yapıldığ 1 birimlerde çalışan hemşirelerin tümü araştırmaya dahil edilerek çalışma 240 hemşire ile yapılmıştır. Hastaların refakatçisinin bulunmadığı ve büyük çoğunluğunu bilinci kapalı hastaların oluşturduğu ünitelerde (yoğun bakım, reanimasyon, ameliyathane ve 
derlenme ünitesi) çalışan hemşireler çalışma dış1 bırakılmıştır.

Verilerin Toplanması: Verilerin toplanmasında araştırmacılar tarafından hazırlanan bir bilgi formu kullanılmıştır (AbuAlRub, 2004; Koçaman, 2015; Ertürk ve Özmen 2018). Bilgi formu iki bölümden oluşmaktadır. Birinci bölüm hemşirelerin demografik ve mesleki özelliklerini içermektedir. İkinci bölüm ise hasta / hasta yakınlarının invaziv işlemler sırasındaki davranış ve tepkilerine ayrıca hemşirelerin bu durumdaki duygu- düşüncelerine yönelik sorulardan oluşmaktadır. Veriler araştırmacı tarafindan hemşirelere açıklama yapılarak verilmiş ve bir hafta sonra geri alınmıştır.

Verilerin Değerlendirilmesi: Veriler SPSS programında (Statistical Package for Social Sciences- 22.0 version) değerlendirilmiştir. Çalışmada tanımlayıcı istatistiksel dağılımlar verilmiştir (sayı, ortalama, standart sapma). Parametrelerin normal dağılıma uygunluğu Shapiro Wilks testi ile incelenmiștir. Ayrıca normal dağılıma uygun olduğu belirlenen verilerin karşılaştırılmasında Ki-Kare testi kullanılmış; anlamlılık düzeyi $\mathrm{p}<0.05$ kabul edilmiştir.

Etik Yön: Çalışma öncesi araştırmanın yürütüldüğ̈̈ kurumdan yazılı izin ve üniversite girişimsel olmayan araştırmalar etik kurulundan onay (Tarih: 25/12/2015 No: 100) alınmıştır. Veriler izin alındıktan sonra toplanmış ve gönüllülük ve mahremiyet ilkesi gereği katılımcın kimlik bilgileri istenmemiştir.

\section{Bulgular}

Tablo 1 de araştırmaya katılan hemşirelerin demografik ve mesleki özellikleri verilmiştir. Hemşirelerin \%39.6'sı 18-25 yaş arasında; \%70.4'ü kadın; \%52.1'i ön lisans / lisans mezunudur ve \%77.9'u üniversite hastanesinde çalışmaktadır. Mesleki özelliklerine açısından ise \%83.3'ünün klinikte hemşire olduğu; \%40'ının meslekte çalışma yılının 1-5 yıl arasında olduğu ve \%53.8'inin vardiyalı çalıştığı görülmektedir.

Tablo 2 hemşireler için stres yaratan faktörler ve invaziv girişimler sırasında hasta ya da yakınlarının hemşirelere tepkisi ile ilgilidir. Hemşireler için stres yaratan faktörlerin \%66.3 oranında hasta ve yakınlarının davranışları ve \%12.5' inin hemşirelik bakımı ve invaziv girişimler olduğu görülmüştür. İnvaziv girişimler sırasında hemşirelerin \%27.5'inin elinin tutulduğu; \%6.3'ünün eline vurulduğu, \%15'inin üstüne yüründüğü, \%31.3'ünün kötü sözler söylendiği, \%49.6'sının kendisiyle yüksek sesle konuşulduğu, \%26.3'ünün konuşmasına izin verilmediği ve \%16.7'sinin tehdit edildiğini ifade ettikleri belirlenmiştir.

Hemşirelerin invaziv girişimler sırasında hasta ve hasta yakınlarından etkilenme biçimleri Tablo 3' de verilmiştir. \%62.9'unun stres yaşadığ 1 ; \%51.3'ünün uygulamalar sirasinda hata yapma korkusu yaşadığı, \%25.4'ünün müdahale edildiğinde hastanın odasına tekrar girmekten çekindiği saptanmıştır.

Hasta ve hasta yakınlarının invaziv girişimler sırasındaki müdahaleleri karşısında hemşirelerin nasıl davrandıklarının dağılımı (Tablo 4) incelendiğinde \%39.6'sının invaziv girişimde başarısız olduğunda diğer sağlık çalışanlarından yardım aldığı; \%55' inin invaziv girişimler sırasında hasta yakınlarını odadan çıkarttığı; \%31.7'sinin odadan çıkmak istemeyen hasta yakınını uyardığ 1 , çıkmazlarsa 1srar etmediği; \%51.7'sinin hasta yakınlarını girişimlerde müdahale etmemesi için uyardığını ifade ettikleri belirlendi.

Bireysel ve mesleki özelliklerine göre invaziv girişimlerle ilgili tepkilerin hemşireler üzerindeki etkisi Tablo 5' de incelendi. Hemşirelerin cinsiyet, eğitim durumları ve meslekte çalışma yılına göre invaziv girişimlerde başarısız olunduğunda gösterilen tavırlar açısından istatistiksel olarak anlamlı farklılık bulundu $(\mathrm{p}<0.05)$. Sağlık meslek lisesi mezunu hemşirelerin hastanın dinlenmesini bekledikten sonra devam etme oranının (\%15.9) diğer hemşirelerden anlamlı şekilde düşük $(\mathrm{p}<0.01)$; meslekte çalışma süresi 6-10 y1l arasında olan hemşirelerin invaziv girişimlerde başarısız olunduğunda hastanın dinlenmesini bekledikten sonra devam etme oranının (\%48.3) diğerlerinden anlamlı şekilde yüksek $(\mathrm{p}<0.05)$; kadın hemşirelerin ise bu oranının erkek hemşirelerden anlamlı şekilde $(p<0.05)$ yüksek olduğu belirlendi.

\section{Tartışma}

Hemşirelik uygulamalı bir sağlık disiplinidir. Sağlıklı/hasta bireyler bakım ortamlarına yakınları ile birlikte başvurmakta ve yattığı süre içinde çoğunlukla bir yakını ile birlikte bulunmaktadır. $\mathrm{Bu}$ nedenle hemşirelik girişimlerinin birçoğu hasta yakınlarının yanında gerçekleştirilmektedir. Girişimlerin gerçekleştirilmesi sırasında hemşire ve hasta/hasta yakını arasında bir etkileşim oluşmaktadır. Ancak bu etkileşim, girişimin başarısı, ağrılı ve rahatsız edici bir uygulama ise olumsuz da olabilmektedir. 
Tablo 1. Hemşirelerin demografik ve mesleki özelliklerinin dağılımı $(\mathrm{n}=240)$

\begin{tabular}{|c|c|c|c|}
\hline Demografik Özellikler & & $\overline{\mathrm{n}}$ & $\%$ \\
\hline \multirow{4}{*}{ Yaş Grupları } & 18-25 yaş & 95 & 39.6 \\
\hline & $26-35$ yaş & 88 & 36.7 \\
\hline & $36-45$ yaş & 40 & 16.7 \\
\hline & 46 ve üzeri & 17 & 7.0 \\
\hline \multirow{2}{*}{ Cinsiyet } & Kadın & 169 & 70.4 \\
\hline & Erkek & 71 & 29.6 \\
\hline \multirow{2}{*}{ Medeni durum } & Evli & 100 & 41.7 \\
\hline & Bekar & 140 & 58.3 \\
\hline \multirow{3}{*}{ Eğitim durumu } & Sağlık meslek lisesi & 82 & 34.1 \\
\hline & Ön lisans/lisans & 125 & 52.1 \\
\hline & Lisansüstü & 33 & 13.8 \\
\hline \multirow[b]{2}{*}{ Çalıştığı kurum } & Üniversite Hastanesi & 187 & 77.9 \\
\hline & Özel Hastane & 53 & 22.1 \\
\hline \multirow{2}{*}{ Görevi } & Servis hemşiresi & 200 & 83.3 \\
\hline & Sorumlu Hemşire & 40 & 16.7 \\
\hline \multirow{4}{*}{ Meslekte Çalışma Yılı } & $0-1 \mathrm{y} 1 \mathrm{l}$ & 34 & 14.1 \\
\hline & $1-5 \mathrm{y} 1 \mathrm{l}$ & 96 & 40.0 \\
\hline & $6-10 \mathrm{y} 11$ & 58 & 24.2 \\
\hline & 11 yil ve üzeri & 52 & 21.7 \\
\hline \multirow{2}{*}{ Mesleği İsteyerek Seçme } & Evet & 169 & 70.4 \\
\hline & Hayır & 71 & 29.6 \\
\hline \multirow{3}{*}{ Çalışma Biçimi } & Vardiya & 129 & 53.8 \\
\hline & Gece & 23 & 9.5 \\
\hline & Gündüz & 88 & 36.7 \\
\hline
\end{tabular}

Tablo 2. Hemşireler için stres yaratan faktörlerin ve hasta ve yakınlarının invaziv girişimler sırasındaki tepkilerinin dağılımı $(\mathrm{n}=240)$

\begin{tabular}{lcc}
\hline \hline Stres Faktörleri * & $\mathbf{n}$ & $\mathbf{( \% )}$ \\
\hline \hline Hasta ve hasta yakınlarının davranışları & 159 & 66.3 \\
Hemşirelik bakımları ve invaziv girişimler & 30 & 12.5 \\
İş yükü ve çalışma koşulları & 124 & 51.7 \\
İşyeri düzeni & 58 & 24.2 \\
Yetersiz personel sayısı & 122 & 50.8 \\
Diğer sağlı personelleri ile çatı̧ma yaşanması & 73 & 30.4 \\
Diğer faktörler & 12 & 5.0 \\
\hline \hline Tepkiler & & \\
\hline \hline El tutma & 66 & 27.5 \\
Ele vurma & 15 & 6.3 \\
Üstüne yürünmesi & 36 & 15.0 \\
Kötü söz söyleme & 75 & 31.3 \\
Yüksek sesle konuşma & 119 & 49.6 \\
Konuşulmasına izin vermeme & 63 & 26.3 \\
Tehdit etme & 40 & 16.7 \\
\hline \hline
\end{tabular}

*Birden fazla seçenek işaretlenmiştir. 
Tablo 3. Hemşirelerin invaziv girişimler sırasında hasta ve hasta yakınlarından etkilenme durumlarının dağılımı $(\mathrm{n}=240)$

\begin{tabular}{|c|c|c|c|}
\hline \multicolumn{2}{|l|}{ Etkilenme } & $\mathbf{n}$ & $\%$ \\
\hline \multirow{2}{*}{ İnvaziv girişimler sırasında stres yaşama } & Evet & 151 & 62.9 \\
\hline & Hayır & 89 & 37.1 \\
\hline \multirow{2}{*}{ Uygulamalar sırasında hata yapma korkusu yaşama } & Evet & 123 & 51.3 \\
\hline & Hayır & 117 & 48.7 \\
\hline \multirow{3}{*}{$\begin{array}{l}\text { Hasta yakınlarının invaziv girişim sırasındaki tavrının } \\
\text { hemşireyi etkilemesi }\end{array}$} & Evet & 84 & 35 \\
\hline & $\overline{\text { Biraz }}$ & 121 & 50.4 \\
\hline & Hayır & 35 & 14.6 \\
\hline \multirow{3}{*}{$\begin{array}{l}\text { Hastaların invaziv girişim sırasındaki tavrının hemşireyi } \\
\text { etkilemesi }\end{array}$} & Evet & 85 & 35.4 \\
\hline & Biraz & 129 & 53.8 \\
\hline & Hayır & 26 & 10.8 \\
\hline \multirow{2}{*}{$\begin{array}{l}\text { İnvaziv girişimlerde müdahale edildiğinde hastanın odasına } \\
\text { tekrar girmekte çekinme }\end{array}$} & Hayır & 179 & 74.6 \\
\hline & Evet & 61 & 25.4 \\
\hline \multirow{2}{*}{$\begin{array}{l}\text { Hasta yakınlarının invaziv girişimler sırasında müdahale } \\
\text { etmesini saygısızlık olarak görme }\end{array}$} & Evet & 154 & 64.2 \\
\hline & Hayır & 86 & 35.8 \\
\hline \multirow{3}{*}{$\begin{array}{l}\text { Hasta yakını konumunda bulunan hemşirelerin invaziv } \\
\text { girişimler uygulanırken müdahale etme }\end{array}$} & Hayır & 130 & 54.2 \\
\hline & $\begin{array}{l}\text { Başarısızlık halinde } \\
\text { müdahale etme }\end{array}$ & 79 & 32.9 \\
\hline & Evet & 31 & 12.9 \\
\hline
\end{tabular}

Tablo 4. Hasta ve hasta yakınlarının invaziv girişimler sırasındaki müdahalelerine karşı hemşirelerin davranışlarının dağılımı $(\mathrm{n}=240)$

\begin{tabular}{lll}
\hline Davranışlar & $\mathbf{n}$ & $\mathbf{\%}$ \\
\hline İnvaziv girişimlerde hasta yakınlarını odadan çıkarma & & 55 \\
Odadan çıkartıyor & 132 & 45 \\
Odadan çıartmıyor & 108 & \\
\hline Hasta yakınlarının odadan çıkmak istememesi halindeki davranış & & 28.8 \\
Fark etmeden işlemin yapılması & 69 & 29.2 \\
Her ne olursa olsun hasta yakınlarını odadan çıkarma & 70 & 31.7 \\
Bir defa uyarma, çıkmazlarsa ısrar etmeme & 76 & 10.1 \\
İstenmese de kalmalarına izin verme & 25 & \\
\hline Hasta yakınları tarafından invaziv girişimler sırasında yönlendirildiği & & \\
düşünüldüğünde yapılan davranış & & 23.3 \\
Hasta yakınlarını odadan çıarma & 56 & 51.7 \\
Hasta yakınlarını girişimlere müdahale etmemesi için uyarma & 124 \\
Hasta yakınlarını duyumsamazlıktan gelme & 29 & 12.1 \\
Hasta yakını ile işbirliği halinde invaziv girişimlerini uygulama & 31 & 12.9 \\
\hline \hline
\end{tabular}

Hemşirelik uygulamalarının çoğunluğunu oluşturan invaziv girişimler, hastada ağrı ve rahatsızlık yaratması nedeniyle hemşireler için stres faktörlerinden birini oluşturmaktadır (Özaltın ve Nehir, 2007; Demir ve ark., 2012;). Özaltın ve Nehir (2007) çalışmalarında iş stresi faktörleri arasında hemşirelerin, hasta ve aileleriyle yaşadıkları sorunları göstermektedirler. Yaptığımız araştırmada da benzer şekilde hemşirelik işlevleri arasındaki en çok stres yaratan faktörlerin, hasta ve hasta yakınlarının davranışları olduğu (\%66.3) ve invaziv girişimlerin daha düşük oranda da $(\% 12.5)$ olsa etkili bir faktör olduğu görülmektedir (Tablo 2). İki faktör bir arada düşünüldüğünde hemşire üzerindeki 
baskının büyüklüğü göze çarpmaktadır; ayrıca hemşirelerin ne kadar büyük strese maruz kaldıklarının da bir göstergesidir.

Genellikle ağrı yaratan invaziv girişimlerin hasta ve yakınları için de stres yaratması kaçınılmazdır.
Kirılgan, kaygilı olan hastalar ve bu durumdaki hastasına girişim yapılan hasta yakınları, rahatsızlık ya da ağrı oluşturan invaziv girişimler karşısında daha fazla ya da farklı tepkiler verebilmektedirler (Özaltın ve Nehir, 2007).

Tablo 5. Bireysel ve mesleki özelliklere göre invaziv girişimlerin hemşire üzerine etkisi

\begin{tabular}{|c|c|c|c|c|c|c|c|c|c|c|c|c|}
\hline \multirow[b]{2}{*}{$\begin{array}{c}\text { Hemşirelerin } \\
\text { Etkilenme Durumu }\end{array}$} & \multicolumn{2}{|c|}{ Cinsiyet } & \multicolumn{3}{|c|}{ Yaş } & \multicolumn{4}{|c|}{ Meslekte Çalışma yılı } & \multicolumn{3}{|c|}{ Eğitim Durumu } \\
\hline & $\begin{array}{l}\text { Kadın } \\
(n=16)\end{array}$ & $\begin{array}{l}\text { Erkek } \\
(\mathrm{n}=71)\end{array}$ & $\begin{array}{c}\mathbf{1 8 - 2 5} \\
\text { yaş } \\
(\mathbf{n}=95)\end{array}$ & $\begin{array}{l}26-35 \\
\text { yaş } \\
(n=88)\end{array}$ & $\begin{array}{c}36 \text { yaş } \\
\text { ve üzeri } \\
(n=57)\end{array}$ & 0-1 yll & $1-5$ yil & $\begin{array}{c}6-10 \\
\text { yil }\end{array}$ & $\begin{array}{l}11 \text { yll } \\
\text { ve } \\
\text { üzeri }\end{array}$ & SML & ÖL/L & Lisansüstü \\
\hline \multirow{2}{*}{$\begin{array}{c}\text { Hemşirelik bakımları ve } \\
\text { invaziv girişimlerin stres } \\
\text { yaratması }(n=30)\end{array}$} & $\begin{array}{c}20 \\
(11.8) \\
\end{array}$ & $\begin{array}{c}10 \\
(14.1)\end{array}$ & $\begin{array}{c}16 \\
(16.8)\end{array}$ & $\begin{array}{c}7 \\
(8) \\
\end{array}$ & $\begin{array}{c}7 \\
(12.3) \\
\end{array}$ & $\begin{array}{c}7 \\
(20.6) \\
\end{array}$ & $\begin{array}{c}14 \\
(14.6) \\
\end{array}$ & $\begin{array}{c}3 \\
(5.2) \\
\end{array}$ & $\begin{array}{c}6 \\
(11.5) \\
\end{array}$ & $\begin{array}{c}9 \\
(11)\end{array}$ & $\begin{array}{c}18 \\
(14.4) \\
\end{array}$ & $\begin{array}{c}3 \\
(9.1) \\
\end{array}$ \\
\hline & \multicolumn{3}{|c|}{$\chi^{2=0.071 \mathrm{p}=0.789}$} & \multicolumn{3}{|c|}{$\chi^{2=}=3.302 \mathrm{p}=0.192$} & \multicolumn{3}{|c|}{$\chi^{2=5.306} \mathrm{p}=0.151$} & \multicolumn{3}{|c|}{$\chi^{2=}=0.937 \mathrm{p}=0.619$} \\
\hline \multirow{5}{*}{ 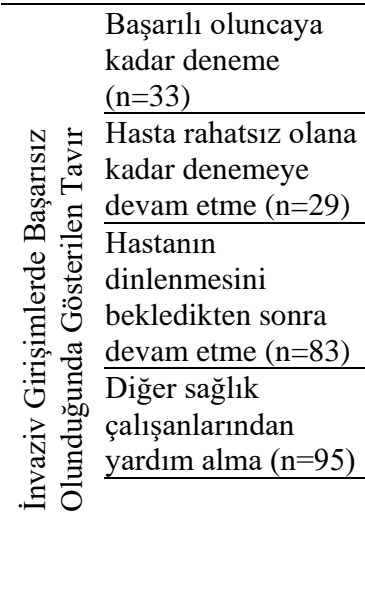 } & $\begin{array}{c}12 \\
(7.1)\end{array}$ & $\begin{array}{c}21 \\
(29.6)\end{array}$ & $\begin{array}{c}20 \\
(21.1)\end{array}$ & $\begin{array}{c}7 \\
(8)\end{array}$ & $\begin{array}{c}6 \\
(10.5)\end{array}$ & $\begin{array}{c}6 \\
(17.6)\end{array}$ & $\begin{array}{c}18 \\
(18.8)\end{array}$ & $\begin{array}{c}5 \\
(8.6)\end{array}$ & $\begin{array}{c}4 \\
(7.7)\end{array}$ & $\begin{array}{c}15 \\
(18.3)\end{array}$ & $\begin{array}{l}15 \\
(12)\end{array}$ & $\begin{array}{c}3 \\
(9.1)\end{array}$ \\
\hline & $\begin{array}{c}18 \\
(10.7)\end{array}$ & $\begin{array}{c}11 \\
(15.5)\end{array}$ & $\begin{array}{c}14 \\
(14.7)\end{array}$ & $\begin{array}{c}11 \\
(12.5)\end{array}$ & $\begin{array}{c}4 \\
(7)\end{array}$ & $\begin{array}{c}7 \\
(20.6)\end{array}$ & $\begin{array}{c}15 \\
(15.6)\end{array}$ & $\begin{array}{c}3 \\
(5.2)\end{array}$ & $\begin{array}{c}4 \\
(7.7)\end{array}$ & $\begin{array}{c}12 \\
(14.6)\end{array}$ & $\begin{array}{c}13 \\
(10.4)\end{array}$ & $\begin{array}{c}4 \\
(12.1)\end{array}$ \\
\hline & $\begin{array}{c}77 \\
(45.6)\end{array}$ & $\begin{array}{c}6 \\
(8.5)\end{array}$ & $\begin{array}{c}25 \\
(26.3)\end{array}$ & $\begin{array}{c}35 \\
(39.8)\end{array}$ & $\begin{array}{c}23 \\
(40.4)\end{array}$ & $\begin{array}{c}7 \\
(20.6)\end{array}$ & $\begin{array}{c}29 \\
(30.2)\end{array}$ & $\begin{array}{c}28 \\
(48.3)\end{array}$ & $\begin{array}{c}19 \\
(36.5)\end{array}$ & $\begin{array}{c}13 \\
(15.9)\end{array}$ & $\begin{array}{c}54 \\
(43.2)\end{array}$ & $\begin{array}{c}16 \\
(48.5)\end{array}$ \\
\hline & $\begin{array}{c}62 \\
(36.7)\end{array}$ & $\begin{array}{c}33 \\
(46.5)\end{array}$ & $\begin{array}{c}36 \\
(37.9)\end{array}$ & $\begin{array}{c}35 \\
(39.8)\end{array}$ & $\begin{array}{c}24 \\
(42.1)\end{array}$ & $\begin{array}{c}14 \\
(41.2)\end{array}$ & $\begin{array}{c}34 \\
(35.4)\end{array}$ & $\begin{array}{c}22 \\
(37.9)\end{array}$ & $\begin{array}{c}25 \\
(48.1)\end{array}$ & $\begin{array}{c}42 \\
(51.2)\end{array}$ & $\begin{array}{c}43 \\
(34.4)\end{array}$ & $\begin{array}{c}10 \\
(30.3)\end{array}$ \\
\hline & \multicolumn{3}{|c|}{$\begin{array}{l}\chi^{2}=40.461 \\
p=0.001 *\end{array}$} & \multicolumn{3}{|c|}{$\begin{array}{c}\chi^{2}=11.314 \\
p=0.079\end{array}$} & \multicolumn{3}{|c|}{$\begin{array}{l}\chi^{2}=17.862 \\
\mathbf{p}=\mathbf{0 . 0 3 6} *\end{array}$} & \multicolumn{3}{|c|}{$\begin{array}{l}\chi^{2}=19.982 \\
p=0.003 *\end{array}$} \\
\hline
\end{tabular}

Ki-Kare Test $p<0,01 \quad$ SML (Sağlık Meslek Lisesi) ÖL/L (Önlisans/lisans)

Özellikle bütünlük duygusunun tehdidi de birlikte olduğunda bu duygular öfkeye dönüşebilir ve öfke ile istenmeyen tepkilere yol açabilir (Kocaman, 2015). Araştırmada literatürü destekler biçimde hasta ve yakınlarının, duygularının ve ağrının etkisi ile olumsuz tavırlar sergiledikleri; hasta ve yakınlarının tepkilerinin en çok yüksek sesle konuşma, hemşireye kötü söz söyleme, hemşirenin konuşmasına izin vermeme, hemşirenin elini tutma, hemşirenin eline vurma, üstüne yürüme, tehdit etme şeklinde gösterdikleri belirlenmiştir (Tablo 2). Hasta ve hasta yakınlarının bu tepki ve müdahaleleri karşısında hemşirelerin invaziv girişimler sırasında stres yaşamaları ve rahatsızlık duymaları kaçınılmaz olacaktır. Bu araştırmada hemşirelerin bu nedenle stres ve hata yapma korkusu yaşadıkları; müdahale edildiğinde hastanın odasına tekrar girmekten çekindikleri görülmektedir (Tablo 3). Ayrıca hasta ve hasta yakınlarının invaziv girişim sırasındaki tavrından etkilenmediğini ifade eden hemşirelerin oranı da çok düşük (\%10.8); etkilendiğini ifade edenlerin oranı ise çok yüksek bulunmuştur. Hemşire, birey/aile toplumun sağlığını ve esenliğini koruma, geliştirme, hastalık durumunda iyileştirmeye yönelik rol ve sorumlulukların tümünde hasta/sağlıklı birey ile etkileşim içerisinde hareket etmektedir (Ay ve ark., 2007). Hastaların ya da yakınlarının ağrılı bir uygulamada tepki göstermesi elbette beklenilen bir durumdur. Ancak profesyonel olarak bu sorumlulukların yerine getirilmesinde yaşanan olumsuz etkileşimle başa çikılması zorlaşabilmektedir. $\mathrm{Bu}$ zorlamaların da stres oluşumunda rol oynayarak hemşireyi etkilemesi söz konusu olabilir. Hemşireler için hasta üzerinde ağrı, endişe, kaygıya neden olan invaziv girişimler başlı başına bir stres faktörüdür (Tel ve ark., 2003). Bir profesyonel olarak uygulansa da hastada ağrı 
yaratan bir girişimin hemşire için stres oluşturması da insani bir duygudur. Ancak önemli olan bu stres ile başa çıkılması ve hastaya yansıtılmamasıdır. Stres, organizmanın bedensel ve ruhsal sinırlarının zorlanması ve tehdit edilmesiyle ortaya çıkan ve bireylerin yaşamlarını etkileyen evrensel bir durumdur (Baltaş ve Baktaş, 2002). Sağlık çalışanları ile yapılan çalışmalarda iş ortamındaki stresörlerin sağlık çalışanlarının beden ve ruh sağlığını olumsuz etkilediği belirtilmektedir (Tel ve ark., 2003; Özaltın ve Nehir, 2007; Taşç1 ve ark., 2007). Araștırmada yer alan hemşirelerin yarısı kendileri bir hastanın yakını olarak hastanede bulunduklarında hastalarına yapılan invaziv bir girişime müdahale etmeyeceğini; \% 33.9' u da ancak başarısızlık durumunda müdahale edebileceğini belirtmektedir (Tablo 3). Bu bulgu hemşirelerin güçlü mesleki aidiyetleri ve bilgileri ile tavır ve davranışlarını etkilediğini düşündürmektedir. Aynı zamanda kendi meslektaşlarının yaşayacağı rahatsızlığın farkında olduklarını da yansıtmaktadır.

İnvaziv girişimler sırasındaki müdahale karşısında hemşirelerin davranışları incelendiğinde, hemşirelerin yarısının girişim sırasında hasta yakınlarını odadan çıkarttığı ya da müdahale etmemeleri için uyardıkları, \%39.6'sının başarısız olduğunda diğer sağlık çalışanlarından yardım aldıkları görüldü (Tablo 4). Etkileşim sırasında duygular bazen davranışlara yön vermektedir (Yalçın ve Aşt1, 2011). Çalışma ortamında yaşanan stresli durumlarda çeşitli baş etme yöntemleri kullanılmakta, kullanılan bu yöntemlerin etkili olmaması ve uzun sürmesi durumunda ise tükenme, depresyon, performansta azalma, işten ayrılma ve kişilerarası ilişkilerde bozulmalar yaşanabilmektedir (Abuairub, 2004). Güvenli bir girişim yapabilmek için risk faktörlerinden bir olan stresin de kontrol altına alınması gerekir. İşlemin yaratacağı stresle baş etmek için yalnız çalışmayı istemek bir stresle baş etme biçimi olabilir. $\mathrm{Bu}$ nedenle hemşireler girişim sırasında hasta yakınını odadan çıkartmak istiyor olabilirler. Hemşireler invaziv girişimlerde başarısız olduklarında; daha çok diğer sağlık çalışanlarından yardım aldıkları (\%39.5) ve hastanın dinlenmesini bekleyerek, dinlendikten sonra devam ettikleri (\%34.5) görüldü. Çok azı hasta rahatsız olana kadar denemeye devam etmekte $(\% 12)$ ya da başarılı oluncaya kadar denemeye devam etmekteydi (\%13.7). Öfkeli hasta ile iletişim sırasında uyaranların en aza indirilmesi sakinlik yaratır ve bireyin rahatlamasına yardım eder (Kocaman, 2015). Girişimler sırasında başarı sağlamadığında ara vermek ve hastanın dinlenmesini sağlamak öfkeye neden olacak uyaranı azaltabilir. Hemşirelerin öncelikli yaklaşımları literetürle uyumludur.

Hemşirelik mesleğinde yaşanan sorunlar ise profesyonelliğe ilişkin görüş ve tutumları olumsuz yönde etkileyebilmektedir (Tarhan ve ark., 2016). Yaş ve mesleki deneyimdeki ilerleme eğitim seviyesinin yükselmesi hemşirelerin profesyonellik algılarını ve tutumlarını olumlu etkileyen önemli değişkenlerdir (Ertürk ve Özmen, 2015). Araştırmada invaziv girişimlerin üzerlerinde stres oluşturduğunu ifade eden hemşirelerin, yaş, cinsiyet, eğitim düzeyi ve meslekte çalışma yılı gibi faktörlere göre değişmediği görüldü (Tablo 5). Buna karşın hemşirelerin invaziv girişimlerde başarısız olunduğunda gösterdikleri davranışlar arasında yaş değişkeni hariç istatistiksel olarak anlamlı farkl111klar olduğu görülmektedir. İnvaziv girişimlerde başarısız olunduğunda hastanın dinlenmesini bekleme, dinlendikten sonra devam etme oranları; kadın hemşirelerde (\%45.6) daha yüksek bulundu. Kadın hemşirelerin doğaları gereği erkek hemşirelerden daha sabırlı olmalarının bu sonucu etkilediği düşünülebilir (Levis et al., 2004). Meslekte çalışma süresi 6-10 yıl arasında olanlarda invaziv girişimlerde başarısız olunduğunda hastanın dinlenmesini bekleme, dinlendikten sonra devam etme oranı, meslekte çalışma süresi daha kısa olanlardan yüksek; ve sağlı meslek lisesi mezunlarında hastanın dinlenmesini bekledikten sonra devam etme oranı (\%15.9), diğerlerinden anlamlı şekilde düşüktü. Yapılan çalışmalarda hemşirelerin eğitim durumu ve mesleki deneyimlerinin artmasının profesyonel tutumlarını olumlu yönde etkilediği gösterilmiştir (Levis ve ark., 2004). Hemşirelik felsefesi ve rollerinin benimsenmesi eğitim seviyesinden etkilenebilmektedir (Beydoğan, 2006). Hemşirelik girişimlerinde bireyin korunması amacıyla yapılan hastayı dinlendirme ya da diğer meslektaşlardan yardım alarak işlemin sürdürülmesi oranlarının yüksek olması; hemşirelik felsefesinin özünü oluşturan yardım etme ve koruma yaklaşımının mesleki deneyim ve eğitim düzeyinden etkilenmesinin bir sonucu olarak da gösterilebilir.

\section{Sonuç ve Öneriler}

Araştırma sonucunda hastalar ve yakınlarının invaziv girişimler sırasında hemşirelere el tutma, ele vurma, üstüne yürüme, kötü söz söyleme, yüksek sesle konuşma, konuşulmasına izin vermeme ve tehdit edilme gibi müdahalelerde bulundukları; 
hemşirelerin invaziv girişimler sırasında stres ve hata yapma korkusu yaşadığı, hasta ya da yakını müdahale etse bile hastanın odasına girmekten çekinmediği, invaziv girişimler sırasında hasta yakınlarını veya ziyaretçileri odadan çıkardığı, girişimin başarısız olduğu durumda hastalarını dinlendirdikten sonra yeniden denedikleri ya da başka bir meslektaşından yardım alarak girişimde bulundukları belirlendi.

$\mathrm{Bu}$ çalışma ile hemşirelerin işe bağlı stres yașama ve bu stresle bașetme durumlarını belirli aralıklarla belirlenmesi ve engelleyici önlemlerin alınması, hasta ve yakınları arasında oluşan stresli durumları yönetebilmesi için etkin başetme yollarını öğrenme ve problem çözme becerilerini geliştirmeye, kendini tanımaya ve girişimci,atılgan tutumlar geliştirmeye yönelik rehberlik ve danışmanlı programları oluşturulması önerilmektedir.

Araştırmanın Etik Yönü/ Ethics Committee Approval: Çalışma öncesi kurumdan yazılı izin ve Haliç Üniversitesi Girişimsel Olmayan Araştırmalar Etik Kurulundan onay alınmıştır (Tarih: 25/12/2015; Sayı:100). Veriler izinler sonrası toplanmıştır. Gönüllülük ve mahremiyet ilkesi gereği katılımcıların isimleri alınmamıştır.

Hakem/Peer-review: Dış hakem değerlendirmesi Yazar Katkısı/Author Contributions: Araştırmanın fikir ve tasarımı; M.K. ve L.Ş., veri toplama; M.K. verilerin analizi; M.K. ve L.Ş., makalenin yazım ve eleştirel incelemesi; L.Ş. ve M.K. tarafından yapılmıştır. Çıkar çatışması/Conflict of interest: Çalışma

kapsamında araştırmanın yazarları arasında, herhangi bir kişisel ve finansal çıkar çatışması bulunmamaktadır

Finansal Destek/Financial Disclosure: Çalışma için finansal destek alınmamıștır

\section{Çalışma Literatüre Ne Kattı?}

- Araştırma hemşirelerin invaziv girişimler sırasında hasta ve yakınlarının tepkilerinden olumsuz etkilendiğini ortaya koymuştur.

- Hemşirelerin hasta ve yakınlarının müdahalelerinden etkilenmelerine rağmen profesyonel davranışlar sergilemeye devam etmeye çalıştıkları belirlenmiştir.

- Stresli durumları yönetme konusunda hemşirelerin güçlendirilmesinin gerekli olduğu gösterilmiştir.

\section{Kaynaklar}

AbuAlRub RF. (2004) Jobstress, job performance and social support among hospital nurses. Journal of Scholarship, 36(1), 73-78.
Akduran F, Özkan H. (2014). Hemşirelikte kavram ve kuram çalışmalarının tarihsel süreci. Özkan H. editör. Hemşirelikte Bilim Felsefe ve Bakımın Temelleri. İstanbul: Akademi Basım, s. 83-97.

Ay F, Ertem ÜT, Özcan NK, Güneş B, Iş1k RD, Savran S. (2007). Temel Hemşirelik Kavramları, İkeler, Uygulamalar. İstanbul, Medikal Yayıncılık, s.5-19.

Baltaş A, Baltaş Z. (2002). Stres ve Başa Çıkma Yolları. 21. Bask1, İstanbul, Remzi Kitabevi, s.23

Bayat M. (2017). Hemşirelik teorileri, modelleri. Karadağ A, Çalışkan N, Göçmen Baykara Z. editörler. Hemşirelik Teori ve Modelleri. İstanbul: Akademi Basım, s.32-52.

Beydoğan HÖ. (2006). Öğretim sürecinde düşünme becerilerinin geliştirilmesi. Gazi Üniversitesi Kırşsehir Eğitim Fakültesi Dergisi, 4(1),157-165.

Brilowski GA, Wendler MC. (2005). An evolutionary conceptanalysis of caring. Journal of Advanced Nursing. 50(6), 641-650.

Cossette S, Caraa C, Ricarda N, Pepin J. (2005). Assessing nurse-patient interactions from a caring perspective: report of the development and preliminary psychometric testing of the Caring Nurse-Patient Interactions Scale. International Journal of Nursing Studies, 42, 673-686.

Demir Y, Aştı T, Karadağ A. (2012). Hemşirelik Esasları. İstanbul, Akademi Basın ve Yayıncılık, s.630-659.

Ertürk C, Özmen D. (2018). Hemşirelerin profesyonel tutumlarını yordayan değişkenlerin belirlenmesi. Dokuz Eylül Üniversitesi Hemşirelik Fakültesi Elektronik Dergisi, 11(3), 191-199

Haworth, SK, Dluhy, NM. (2001). Holistic symptom management: Modelling the interaction phase. Journal of Advanced Nursing, 36 (2), 302-310.

Holland K, Jenkins J, Solomon J, Whittam S. (2008). Applying the Roper Logan Tierney Model in Practice. China, Churchill Living Stone, p.2-23.

Koçaman N. (2015). Sağlık bakım profesyonelleri ile hasta iletişimi. Sabuncu N, Akça Ay F. Editörler. Klinik Beceriler: Sağlığın Değerlendirilmesi, Hasta Bakım ve Takibi. İstanbul: Nobel Tıp Kitabevleri, s.162-195

Lewis RW, Fugl-Meyer KS, Bosch R. (2004). Epidemiology/risk factors of sexual dysfuntion. Journal of Sexual Medicine, 1(1), 35-39.

Özaltın G, Nehir S. (2007). Ankara ilindeki hastanelerin yoğun bakım ünitelerinde çalışan hemşirelerin iş ortamındaki stres etkenleri ve kullandıkları başetme yöntemlerinin belirlenmesi. Anadolu Hemşirelik ve Sağlık Bilimleri Dergisi, 10(3), 60-68.

Özcan A. (2006). Hemşire- Hasta İlişkisi ve İletişim. 2.Bask1, Ankara, Sistem Ofset, s.1-260

Potter PA, Perry AG, Stockert P, Hall A. (2009). Fundamentals of Nursing, 9th Ed., St Louis, Elsevier Mosby Company, p.1-14, p.316-36. 
Sabuncu N, Akça Ay F. (2015). Sözlük. Sabuncu N, Akça Ay F. Editörler. Klinik Beceriler: Sağlığın Değerlendirilmesi, Hasta Bakım ve Takibi. İstanbul: Nobel Tip Kitabevleri, s. 896.

Toru F. (2020). Hemşirelik uygulamalarının kilit noktası: bireyselleştirilmiş bakım. Adnan Menderes Üniversitesi Sağlık Bilimleri Fakültesi Dergisi, 4(1), 46-59.

Tarhan G, Kılıç D, Yıldız E. (2016). Hemşirelerin mesleğe yönelik tutumları ile mesleki profesyonellikleri arasındaki ilişkinin incelenmesi. Gülhane Tıp Dergisi, 58, 411-416.

Taşçı KD, Gök Özer F, Koştu N. (2007). Pamukkale üniversitesi hastanesinde çalışan hemşirelerin stresle baş etme stratejilerinin belirlenmesi. Anadolu Hemşirelik ve Sağlık Bilimleri Dergisi, 10(2), 41-48.

Tel H, Karadağ M, Tel H, Aydın Ş. (2003). Sağlık çalışanlarının çalışma ortamındaki stres yaşantıları ile baş etme durumlarının belirlenmesi. Hemşirelikte Araştırma Geliştirme Dergisi, 2, 13-23.

Tutuk A, Al D, Doğan S. (2002). Hemşirelik öğrencilerinin iletişim becerisi ve empati düzeylerinin belirlenmesi. Cumhuriyet Üniversitesi Hemşirelik Yüksek Okulu Dergisi, 6(2), 36-41.

Yalçın Atar N, Atabek Aştı T. (2012). Bakım odaklı hemşire-hasta etkileşimi ölçeğinin güvenirlik ve geçerliği. İstanbul Üniversitesi Florence Nightingale Hemşirelik Dergisi, 20(2), 129-139.

Yalçın N, Aştı T. (2011). Hemşire-hasta etkileşimi. İstanbul Üniversitesi Florence Nightingale Hemşirelik Yüksekokulu Dergisi, 19(1), 54-59.

Zungolo EH. (2003). Nursing and academic mergers of the health sciences: a critique. Nursing Outlook, 51(2), 52-58 